\title{
THE
}

\section{Greenhouse Gas Emissions from Advanced Nitrogen-Removal Onsite Wastewater Treatment Systems}

\author{
Bianca Ross \\ University of Rhode Island \\ Brittany V. Lancellotti \\ Elizabeth Q. Brannon \\ George W. Loomis \\ University of Rhode Island, gloomis@uri.edu \\ José A. Amador \\ University of Rhode Island, jamador@uri.edu \\ Follow this and additional works at: https://digitalcommons.uri.edu/nrs_facpubs
}

The University of Rhode Island Faculty have made this article openly available.

Please let us know how Open Access to this research benefits you.

This is a pre-publication author manuscript of the final, published article.

Terms of Use

This article is made available under the terms and conditions applicable towards Open Access Policy Articles, as set forth in our Terms of Use.

\section{Citation/Publisher Attribution}

Ross, B. N., Lancellotti, B. V., Brannon, E. Q., Loomis, G. W., \& Amador, J. A. (2020). Greenhouse Gas Emissions from Advanced Nitrogen-Removal Onsite Wastewater Treatment Systems. Science of The Total Environment, 737, 140399. doi: 10.1016/j.scitotenv.2020.140399

Available at: https://doi.org/10.1016/j.scitotenv.2020.140399

This Article is brought to you for free and open access by the Natural Resources Science at DigitalCommons@URI. It has been accepted for inclusion in Natural Resources Science Faculty Publications by an authorized administrator of DigitalCommons@URI. For more information, please contact digitalcommons-group@uri.edu. 


\title{
Greenhouse Gas Emissions from Advanced Nitrogen-Removal Onsite Wastewater Treatment Systems
}

\author{
Bianca N. Ross*, Brittany V. Lancellotti, Elizabeth Q. Brannon, George W. Loomis, \\ and Jose A. Amador
}

*Corresponding author: Bianca N. Ross

E-mail: bpeixoto10@uri.edu

T: (401) 874-2902

Bianca N. Ross, Jose A. Amador

Affiliation/address: Laboratory of Soil Ecology and Microbiology, University of Rhode Island, 1 Greenhouse Rd., Kingston, RI 02881, USA

Bianca N. Ross:

E-mail: bpeixoto10@uri.edu

Jose A. Amador

E-mail: jamador@uri.edu

Brittany V. Lancellotti

Affiliation/address: Rubenstein School of Environment and Natural Resources, University of Vermont, 81 Carrigan Dr., Burlington, VT 05405, USA

E-mail: blancell@uvm.edu

Elizabeth Q. Brannon

Affiliation/address: Gloucester Marine Genomics Institute, 417 Main Street, Gloucester, MA 01930, USA

E-mail: ebrannon@uri.edu

George W. Loomis

Affiliation/address:

New England Onsite Wastewater Training Center, University of Rhode Island, 102 Coastal Institute, 1 Greenhouse Rd., Kingston, RI 02881, USA

E-mail: gloomis@uri.edu

Keywords: Onsite wastewater treatment systems, carbon dioxide, methane, nitrous oxide, biological nitrogen removal, greenhouse gases 


\title{
Graphical Abstract
}

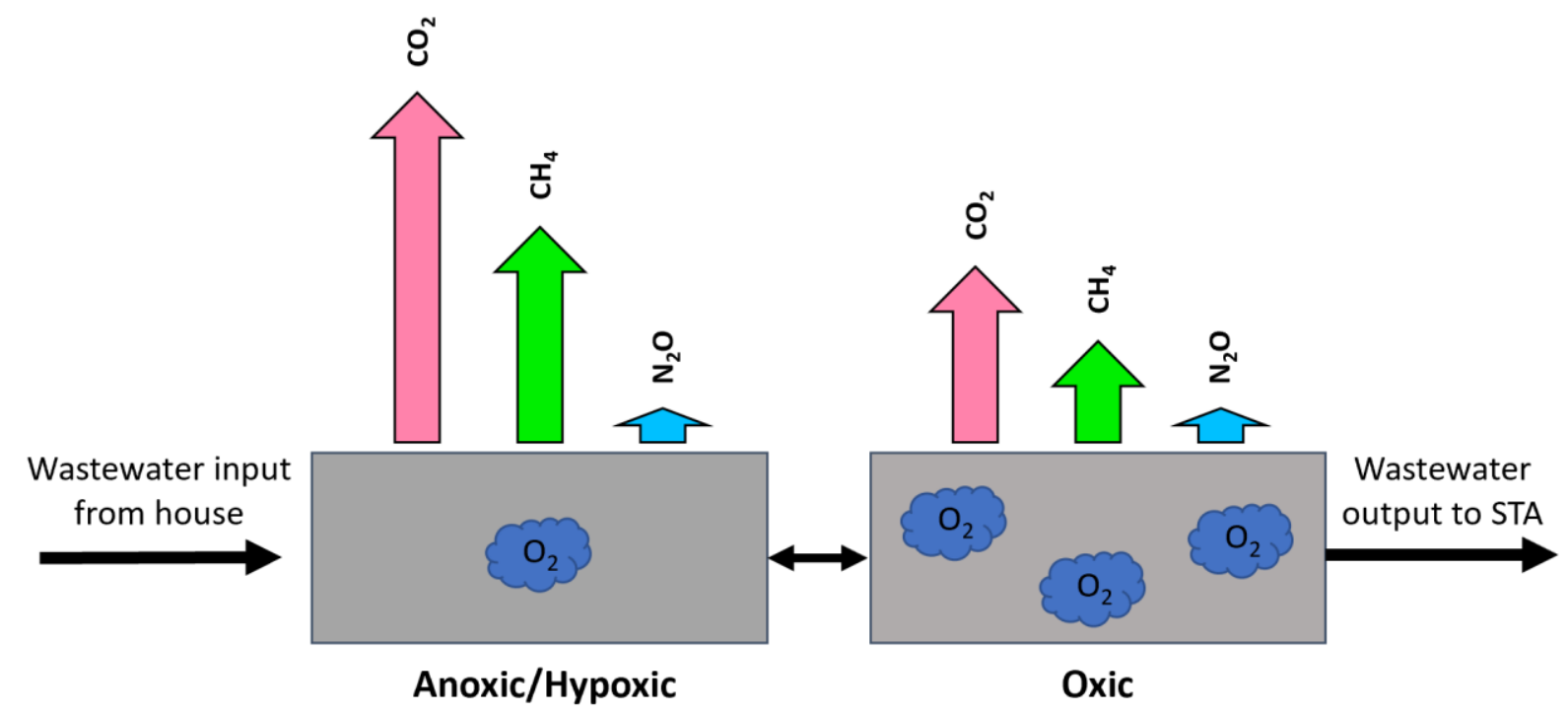

\begin{abstract}
Advanced onsite wastewater treatment systems (OWTS) designed to remove nitrogen from residential wastewater play an important role in protecting environmental and public health. Nevertheless, the microbial processes involved in treatment produce greenhouse gases (GHGs) that contribute to global climate change, including $\mathrm{CO}_{2}, \mathrm{CH}_{4}, \mathrm{~N}_{2} \mathrm{O}$. We measured $\mathrm{GHG}$ emissions from 27 advanced N-removal OWTS in the towns of Jamestown and Charlestown, Rhode Island, USA, and assessed differences in flux based on OWTS technology, home occupancy (year-round $v s$. seasonal), and zone within the system (oxic vs. anoxic/hypoxic). We also investigated the relationship between flux and wastewater properties. Flux values for $\mathrm{CO}_{2}$,

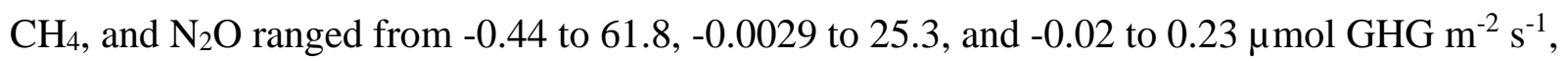
respectively. $\mathrm{CO}_{2}$ and $\mathrm{N}_{2} \mathrm{O}$ flux varied among technologies, whereas occupancy pattern did not significantly impact any GHG fluxes. $\mathrm{CO}_{2}$ and $\mathrm{CH}_{4}-$ but not $\mathrm{N}_{2} \mathrm{O}$ - flux was significantly higher in the anoxic/hypoxic zone than in the oxic zone. Greenhouse gas fluxes in the oxic zone were not related to any wastewater properties. $\mathrm{CO}_{2}$ and $\mathrm{CH}_{4}$ flux from the anoxic/hypoxic zone peaked at $\sim 22-23^{\circ} \mathrm{C}$, and was negatively correlated with dissolved oxygen levels, the latter
\end{abstract}


suggesting that $\mathrm{CO}_{2}$ and $\mathrm{CH}_{4}$ flux result primarily from anaerobic respiration. Ammonium concentration and $\mathrm{CH}_{4}$ flux were positively correlated, likely due to inhibition of $\mathrm{CH}_{4}$ oxidation by $\mathrm{NH}_{4}{ }^{+} . \mathrm{N}_{2} \mathrm{O}$ flux in the anoxic/hypoxic zone was not correlated to any wastewater property. We estimate that advanced $\mathrm{N}$-removal OWTS contribute $262 \mathrm{~g} \mathrm{CO}_{2}$ equivalents capita ${ }^{-1}$ day $^{-1}$, slightly lower than emissions from conventional OWTS. Our results suggest that technology influences $\mathrm{CO}_{2}$ and $\mathrm{N}_{2} \mathrm{O}$ flux and zone influences $\mathrm{CO}_{2}$ and $\mathrm{CH}_{4}$ flux, while occupancy pattern does not appear to impact GHG flux. Manipulating wastewater properties, such as temperature and dissolved oxygen, may help mitigate GHG emissions from these systems.

\section{Introduction}

Wastewater can be a major source of nitrogen $(\mathrm{N})$ to groundwater and coastal waters. Decentralized, advanced N-removal onsite wastewater treatment systems (OWTS) are used to mitigate the impact of excess $\mathrm{N}$ from wastewater on receiving waters, which includes eutrophication, fish and shellfish kills, and threats to public health (Carpenter et al., 1998; Sohail \& Adeloju, 2016; Ward et al., 2005). Advanced OWTS remove N by cycling wastewater through a treatment train that includes oxic and anoxic/hypoxic zones that promote successive nitrification (microbial oxidation of $\mathrm{NH}_{4}{ }^{+}$to $\mathrm{NO}_{3}{ }^{-}$) and denitrification (microbial reduction of $\mathrm{NO}_{3}{ }^{-}$to $\mathrm{N}_{2} \mathrm{O}$ and $\mathrm{N}_{2}$ ). When denitrification proceeds to completion, $\mathrm{NO}_{3}{ }^{-}$is reduced to harmless $\mathrm{N}_{2}$; however, incomplete denitrification produces $\mathrm{N}_{2} \mathrm{O}$, a potent greenhouse gas $(\mathrm{GHG})$ with 265 times the global warming potential of $\mathrm{CO}_{2}$ (Jones et al., 2013; Tomaszek and Czarnota, 2015; Wrage et al., 2001). Advanced N-removal OWTS also emit $\mathrm{CO}_{2}$, which is produced by microbial respiration - including processes that remove organic matter - and methane $\left(\mathrm{CH}_{4}\right)$, which is produced by Archaea under anoxic conditions (Kong et al., 2016).

Greenhouse gas emissions from centralized wastewater treatment plants (WTPs) have been quantified (Cakir \& Stenstrom, 2005; Foley et al., 2010; Kong et al., 2016; Parravicini et 
al., 2016). Nationwide, the U.S. Environmental Protection Agency (USEPA) estimates that centralized WTPs treating domestic wastewater in the U.S. contribute 9.2 and 4.9 million metric tons of $\mathrm{CO}_{2}$ equivalents of $\mathrm{CH}_{4}$ and $\mathrm{N}_{2} \mathrm{O}$, respectively, to the atmosphere every year (USEPA, 2015). In 2010, domestic wastewater treatment at WTPs accounted for $1.4 \%$ of U.S. $\mathrm{N}_{2} \mathrm{O}$ emissions, and domestic and industrial wastewater treatment combined accounted for $2.4 \%$ of $\mathrm{CH}_{4}$ emissions (USEPA, 2015). Assessment of GHG emissions from WTPs typically excludes $\mathrm{CO}_{2}$ due to its biogenic origins (Doorn et al., 2006). However, recent studies have shown that non-biogenic $\mathrm{CO}_{2}$ emissions from various $\mathrm{C}$-containing household and personal care products can significantly contribute to GHG emissions from WTPs, and should be included in emissions analysis (Griffith, et al., 2009; Law et al., 2013; Tseng et al., 2016).

Unlike WTPs, few studies have quantified GHG emissions from OWTS, which serve nearly one quarter of households in the U.S. (U.S. Census Bureau, 2017). Diaz-Valbuena et al. (2011) investigated $\mathrm{CO}_{2}, \mathrm{CH}_{4}$, and $\mathrm{N}_{2} \mathrm{O}$ emissions from conventional OWTS - consisting of a septic tank where gravity-separation of wastewater solids takes place, and the clarified effluent is treated below ground using soil-based treatment - and found net emission of all three GHGs at all study sites, with average values $\left(\mathrm{g}_{\text {capita }}{ }^{-1} \mathrm{day}^{-1}\right.$ ) of 33.3 for $\mathrm{CO}_{2}, 11$ for $\mathrm{CH}_{4}$, and 0.005 for $\mathrm{N}_{2} \mathrm{O}$. Truhlar et al. (2016) assessed $\mathrm{CO}_{2}, \mathrm{CH}_{4}$, and $\mathrm{N}_{2} \mathrm{O}$ emissions from various components of a conventional OWTS treatment train, including the roof vent (which releases gases generated in the septic tank to the atmosphere) and the soil treatment area (STA). They also found net emission of GHGs from all components, with 0.17 and 0.050 tonnes $\mathrm{CO}_{2}$ equivalents capita ${ }^{-1}$ year $^{-1}$ from the roof vent and STA, respectively. Somlai-Haase et al. (2017) found that the STA for a conventional OWTS emitted $15.0 \mathrm{~kg}$ more $\mathrm{CO}_{2}$ per year than a similarly sized control area 
that received no wastewater inputs, further highlighting the contribution of OWTS to global GHG emissions.

Emissions of $\mathrm{N}_{2} \mathrm{O}$ from advanced N-removal OWTS were first quantified by Brannon et al. (2017). They compared emissions of $\mathrm{N}_{2} \mathrm{O}$ from nine advanced $\mathrm{N}$-removal OWTS representing three different technologies - to emissions from a WTP with a biological N removal (BNR) component that also relies on successive nitrification and denitrification. They found that the flux of $\mathrm{N}_{2} \mathrm{O}$ ranged from $-4 \times 10^{-3}$ to $3 \times 10^{-1} \mu \mathrm{mol} \mathrm{N}_{2} \mathrm{O} \mathrm{m} \mathrm{m}^{-2} \mathrm{~s}^{-1}$ and was typically higher for the WTP, followed by the three advanced N-removal treatment technologies. However, when emissions were normalized by treatment tank area and number of people served, the ranges of emissions for the WTP and the advanced N-removal technologies overlapped. Carbon dioxide equivalents - calculated based on $\mathrm{N}_{2} \mathrm{O}$ emissions from the N-removal OWTS - ranged from 1.6 $\times 10^{-3}$ to $8 \times 10^{-2}$ tonnes $\mathrm{CO}_{2}$ equivalents capita ${ }^{-1} \mathrm{yr}^{-1}$.

As the world's population increases, the number of OWTS will also increase (Amador \& Loomis, 2018). The relatively low cost of installation and limited maintenance required make them viable wastewater treatment options, especially in areas with low population densities. Advanced N-removal OWTS will be particularly critical in addressing eutrophication of coastal ecosystems and groundwater contamination. Because wastewater treatment produces GHGs, we need to consider whether their use shifts the pollution stream from ground and surface waters to the atmosphere. As such, we need to develop a better understanding of the magnitude and composition of GHG emissions from OWTS - including advanced N-removal systems - and the factors that control them.

We quantified the flux of $\mathrm{CO}_{2}, \mathrm{CH}_{4}$, and $\mathrm{N}_{2} \mathrm{O}$ from five different advanced $\mathrm{N}$-removal OWTS technologies in the towns of Charlestown and Jamestown, Rhode Island, USA: 
SeptiTech ${ }^{\circledR}$ Series D, Orenco Advantex ${ }^{\circledR}$ AX20, Orenco Advantex ${ }^{\circledR}$ RX30, BioMicrobics MicroFAST®, and Norweco Singulair®. We measured GHG flux in the summer and fall of 2016, and summer and winter of 2018. Because differences in home occupancy pattern may drive differences in microbial activity and the GHGs produced by this activity, we assessed the relationship between home occupancy patterns and GHG emissions by sampling systems used year-round and systems only used during the summer season. GHG emissions result from microbial processes that respond to environmental conditions and availability of nutrients, electron acceptors, and organic $\mathrm{C}$, and thus we assessed the relationship between gas emissions and effluent temperature, $\mathrm{pH}$, and dissolved oxygen (DO), as well as effluent 5-day biochemical oxygen demand ( $\mathrm{BOD}_{5}$; a proxy for organic $\left.\mathrm{C}\right)$, ammonium, nitrate, and total $\mathrm{N}$ concentration. We also quantified emissions per capita in terms of $\mathrm{CO}_{2}$ equivalents to allow for comparison with other types of wastewater treatment.

\section{Methods}

\section{Study Systems and Measurement Locations}

We measured $\mathrm{CO}_{2}, \mathrm{CH}_{4}$, and $\mathrm{N}_{2} \mathrm{O}$ emissions, and determined wastewater properties from a total of 27 advanced N-removal OWTS serving single-family homes in the towns of Jamestown and Charlestown, Rhode Island, USA. Sites were chosen in collaboration with the Rhode Island Department of Environmental Management (RIDEM) and the Office of Wastewater Management in each town. All the sites included in this study rely on well water for potable water and discharge effluent to a low-pressure dosed soil treatment area using a pump. Sites were selected based on adherence to these criteria, as well as the homeowners' willingness to participate in the study. Data from Jamestown sites were collected in June and October of 2016, and data from Charlestown sites were collected in July/August and December of 2018. 
We sampled 9 systems in Jamestown (3 SeptiTech® Series D, 3 Orenco Advantex® AX20, and 3 BioMicrobics MicroFAST®), and 18 sites in Charlestown (6 Orenco Advantex® AX20, 6 Orenco Advantex® RX30, 3 BioMicrobics MicroFAST®, and 3 Norweco Singulair® (models 960 and DN)). All 9 systems sampled in 2016 served homes occupied year-round. Of the systems sampled in 2018, 11 served homes occupied year-round and 7 served seasonallyoccupied homes (June to September). Sampling from systems occupied seasonally and yearround allowed us to examine differences due to home occupancy. We assessed occupancy pattern based on daily flow data obtained from each system, as well as homeowner selfidentification (Ross et al., 2020a).

Although specific design configurations vary by technology, all of the systems in this study have an oxic zone for nitrification (referred to as H-OX) and an anoxic/hypoxic zone for denitrification (referred to as L-OX) (see Supplemental Materials for individual technology designs/descriptions). On every sampling event we measured the flux of GHG and obtained a sample of wastewater from the oxic (H-OX) and anoxic/hypoxic (L-OX) zones of the treatment train. To avoid impacting GHG emissions from disturbance of the wastewater, GHG flux measurements were made prior to wastewater sampling.

\section{Greenhouse Gas Flux Measurements}

At each study site $\mathrm{CO}_{2}, \mathrm{CH}_{4}$, and $\mathrm{N}_{2} \mathrm{O}$ flux measurements were made using a closed chamber connected to a Gas Concentration Analyzer (Model G2518; Picarro, Inc., Santa Clara, CA), which uses cavity ring-down spectroscopy to measure GHG concentration every 2 seconds, providing real-time flux measurements in the field (Crosson, 2008). To measure gas flux, we placed an open-bottom cylindrical PVC chamber (0.13-m internal dia., 0.40-m length) on the 
water so that the bottom of the chamber was submerged $7.5 \mathrm{~cm}$ below the water surface (Brannon et al., 2017). Air temperature inside the chamber was measured every 10 seconds using a Hobo® data logger (Onset, Bourne, MA). To maintain a consistent submersion depth, the chamber was equipped with a stabilizing bar that rested across the top of the system's access riser. The chamber was deployed for 5 to 10 minutes at each site, providing ample time for gas emissions to travel between the system and the gas analyzer (Brannon et al., 2017). The concentration of each gas was plotted against time and the data fitted using a linear regression as part of the flux calculation. An example of the increase of GHG concentrations over time can be found in the Supplemental Materials. We used R statistical software to determine the statistical significance of each gas flux value (R Core Team, 2017), as described in Brannon et al. (2017). GHG flux values below the detection limits of the instrument, and those with a $p$ value $>0.05$ for the slope of the linear regression, were assigned a value of zero. Fluxes above the upper detection limits of the instrument were excluded from our analysis. We calculated per capita $\mathrm{CO}_{2}$ equivalents $\left(\mathrm{CO}_{2} \mathrm{e}\right)$ as described in Brannon et al. (2017) using global warming potential values published by the IPCC (2014).

\section{Wastewater Analysis}

Effluent collected from each zone was transferred to a clear, 1-L plastic bottle. Part of the sample was used for in situ determination of temperature, $\mathrm{pH}$ and dissolved oxygen concentration (DO), and the remainder was stored in the dark at $4{ }^{\circ} \mathrm{C}$ and transported to the laboratory for analysis (within $8 \mathrm{~h}$ of sampling). A Hanna Instruments HI9828 Multiparameter Meter (Woonsocket, RI) was used to determine effluent temperature, $\mathrm{pH}$, and DO. Upon arrival at the laboratory, effluent was analyzed for $\mathrm{BOD}_{5}$ with an OxiTop $\mathrm{BOD}_{5}$ measurement system 
(WTW, Weilheim, Germany). Ammonium, nitrate, and total $\mathrm{N}$ were analyzed using standard laboratory colorimetric analysis (Ross et al., 2018). Values below the detection limit of a method were assigned a value of zero. A summary of wastewater properties for each zone can be found in the Supplemental Materials (Table S1).

\section{Statistical Analyses}

We used R (R Core Team, 2017) to perform a one-way ANOVA on ranks to examine statistical differences in GHG fluxes among technologies, and a Mann-Whitney U test to assess flux differences between zones (L-OX vs. H-OX) and between home occupancy patterns (seasonal vs. year-round). Dunn's test was used for ANOVA post-hoc analysis. In data represented by box and whisker plots, the solid line in the middle of each box represents the median and the edges of each box represents the first and third quartiles. Box whiskers extend $1.5 \times$ the inter-quartile range beyond the edges of the box and the dots represent outliers beyond $1.5 \times$ the inter-quartile range.

We used SigmaPlot v11.0 and Microsoft Excel to carry out linear and nonlinear regression analyses to assess the relationship between wastewater parameters and GHG fluxes. We added 1 as necessary to flux, DO, and nitrate measurements to eliminate negative and zero values, which preclude the use of some nonlinear regression models. We used a $p$ value of less than or equal to 0.05 as a measure of statistical significance.

\section{Results and Discussion}

\section{Carbon dioxide flux}

Across all technologies, zones, occupancy patterns, and sampling events, $\mathrm{CO}_{2}$ flux ranged from -0.44 to $61.8 \mu \mathrm{mol} \mathrm{CO} \mathrm{m}^{-2} \mathrm{~s}^{-1}(n=78)$ (Fig. 1). The Advantex AX20 systems 
produced the highest median $\mathrm{CO}_{2}$ flux $\left(\mu \mathrm{mol} \mathrm{CO}_{2} \mathrm{~m}^{-2} \mathrm{~s}^{-1}\right.$ ) (range of -0.23 to $\left.61.8 ; n=24\right)$, followed by Norweco Singulair (range of -0.44 to 20.42; $n=6$ ), Advantex RX30 (range of 0 to 33.64; $n=19$ ), BioMicrobics MicroFAST (range of 0.1 to $10.62 ; n=18$ ), and SeptiTech (range of 0 to $5.32 ; n=11$ ). Negative $\mathrm{CO}_{2}$ flux values were observed in two systems, likely due to the alkaline $\mathrm{pH}$ of effluent (8.51 and 7.38) in these systems, which promotes the dissolution of atmospheric $\mathrm{CO}_{2}$ in water (Renforth, 2019).

The flux of $\mathrm{CO}_{2}$ varied significantly by technology, with AX20 systems producing significantly higher $\mathrm{CO}_{2}$ emissions than FAST systems, suggesting that system design - which differs considerably between AX20 and FAST systems (Supplemental Materials) - may influence $\mathrm{CO}_{2}$ emissions. FAST systems rely on fixed activated sludge for advanced effluent treatment and are socially-dosed, while AX20 systems utilize a textile filter and are time-dosed. Variations in system dosing mechanism and treatment train design may drive differences in the microbial activity responsible for $\mathrm{CO}_{2}$ emissions.

When values for all technologies were considered, $\mathrm{CO}_{2}$ emissions were significantly higher in L-OX (anoxic/hypoxic zone) than in H-OX (oxic zone) (Fig. 2). L-OX typically contains significantly higher $\mathrm{BOD}_{5}$ concentrations than $\mathrm{H}-\mathrm{OX}$, which can fuel anaerobic respiration in L-OX, where anoxic/hypoxic conditions prevail. The lower amount of organic substrate available for aerobic respiration in $\mathrm{H}-\mathrm{OX}$ may result in lower $\mathrm{CO}_{2}$ emissions.

When we considered values across all technologies, $\mathrm{CO}_{2}$ flux did not differ based on home occupancy pattern (Fig. 3). Studies by Ross et al. (2020) found that home occupancy pattern did not impact treatment performance (Ross et al., 2020a) or microbial community structure or composition (Ross et al., 2020b). These results suggest that the seasonally-used 
systems' microbial communities are robust enough to endure months of not receiving wastewater inputs without compromising their biological activity, as evidenced by similar fluxes of $\mathrm{CO}_{2}$.

\section{Methane Flux}

Across all technologies, zones, home occupancy patterns, and sampling events, $\mathrm{CH}_{4}$ flux ranged from -0.0029 to $25.3 \mu \mathrm{mol} \mathrm{CH}_{4} \mathrm{~m}^{-2} \mathrm{~s}^{-1}(n=79)$ (Fig. 1). The Advantex RX30 systems produced the highest median $\mathrm{CH}_{4}$ flux $\left(\mu \mathrm{mol} \mathrm{CH}_{4} \mathrm{~m}^{-2} \mathrm{~s}^{-1}\right)(0$ to 25.3: $n=19)$, followed by Norweco Singulair (0 to $13.4 ; n=6$ ), Advantex AX20 (0 to $24.7 ; n=25)$, SeptiTech (0 to $2.78 ; n$ $=11$ ), and Biomicrobics MicroFAST (0 to 8.42; $n=18)$. Flux did not differ significantly among technologies or between occupancy patterns (Fig. 3), but L-OX consistently produced significantly higher $\mathrm{CH}_{4}$ fluxes than $\mathrm{H}-\mathrm{OX}$ (Fig. 2). Yan et al. (2014) investigated GHG emissions from WTPs employing various methods of wastewater treatment. They found that for all methods assessed, $\mathrm{CH}_{4}$ emissions were significantly higher in the "grit tank" of the treatment trains, which serves a similar purpose as that of the anoxic/hypoxic zone of advanced N-removal OWTS (L-OX), than those from the oxic zones.

\section{Nitrous Oxide Flux}

Across all technologies, zones, home occupancy patterns, and sampling events, $\mathrm{N}_{2} \mathrm{O}$ flux ranged from -0.02 to $0.23 \mu \mathrm{mol} \mathrm{N}_{2} \mathrm{O} \mathrm{m}^{-2} \mathrm{~s}^{-1}$ ( $n=78$; Fig. 1 ). Seventeen $\mathrm{N}_{2} \mathrm{O}$ flux values were either statistically insignificant or below the instrument's detection limit, and were thus assigned a value of 0 . The Norweco Singulair systems produced the highest median $\mathrm{N}_{2} \mathrm{O}$ flux $\left(\mu \mathrm{mol} \mathrm{N}_{2} \mathrm{O}\right.$ $\mathrm{m}^{-2} \mathrm{~s}^{-1}$ ) (range of -0.01 to $0.1 ; n=6$ ), and exhibited far more variability than the other technologies, all of which had a median $\mathrm{N}_{2} \mathrm{O}$ flux of 0: Advantex AX20 $(n=24)$ had a range of - 
0.01 to 0.07 ; Biomicrobics MicroFAST $(n=18)$ had a range of -0.02 to 0.23 ; Advantex RX30 ( $n$ $=19)$ had a range of 0 to 0.03 ; and the range for $\operatorname{SeptiTech}(n=11)$ was 0 to 0.01 . The variability observed in flux measurements from Norweco systems may be due to intermittent on/off cycles of aeration to facilitate successive nitrification and denitrification, and when we sampled within that cycle.

Nitrous oxide flux varied significantly by technology, with RX30 systems producing significantly higher $\mathrm{N}_{2} \mathrm{O}$ emissions than SeptiTech systems, suggesting that system design, which differs considerably between these two technologies (Supplemental Materials), may influence $\mathrm{N}_{2} \mathrm{O}$ flux. Although both technologies utilize textile filters for advanced effluent treatment, they differ in the type of media material used, as well as in wastewater dosing mechanism. As was the case for differences in dosing mechanism between AX20 and FAST systems (which differed significantly in their $\mathrm{CO}_{2}$ emissions), $\mathrm{RX} 30$ systems are time-dosed while SeptiTech systems are socially-dosed. The porous nature of the textile material and the time dosing employed by RX30 systems may enhance $\mathrm{N} 2 \mathrm{O}$ production by denitrification and/or nitrification.

System zone did not significantly impact $\mathrm{N}_{2} \mathrm{O}$ flux (Fig. 2) indicateing that processes that produce $\mathrm{N}_{2} \mathrm{O}$, such as nitrification and incomplete denitrification, take place to the same extent in both zones. Wigginton et al. (2020) found that the structure and composition of communities of ammonia oxidizing and denitrifying bacteria in these two zones in nine advanced $\mathrm{N}$-removal OWTS did not differ significantly, suggesting a similar potential for $\mathrm{N}_{2} \mathrm{O}$ production via these processes. As was the case for the other two gases, $\mathrm{N}_{2} \mathrm{O}$ flux was not influenced by home occupancy pattern, mirroring the fact that the structure and composition of the microbial communities of seasonal and year-round systems were similar (Fig. 3). 
Our values are comparable to those reported by Brannon et al. (2017) of - 0.004 to 0.3 $\mu$ mol $\mathrm{N}_{2} \mathrm{O} \mathrm{m} \mathrm{m}^{-2} \mathrm{~s}^{-1}$, which included nine of the same advanced $\mathrm{N}$-removal OWTS sampled in this study. Negative $\mathrm{N}_{2} \mathrm{O}$ fluxes were reported from a BNR wastewater treatment plant by Brannon et al. (2017), and net $\mathrm{N}_{2} \mathrm{O}$ consumption has been observed in soil and aquatic environments (Beaulieu et al., 2015; Chapuis-lardy et al., 2007; Soued et al., 2016). The final step of denitrification consumes $\mathrm{N}_{2} \mathrm{O}$ as it is reduced to $\mathrm{N}_{2}$, which takes place under hypoxic and anoxic conditions when nitrate is available as the terminal electron acceptor (Chapuis-Lardy et al., 2007). Because complete denitrification increases with decreased DO, the amount of $\mathrm{N}_{2} \mathrm{O}$ produced from incomplete denitrification is largely dependent on DO. Six of the 7 negative $\mathrm{N}_{2} \mathrm{O}$ values came from L-OX, the anoxic/hypoxic zone, suggesting that DO concentration played an important role in controlling $\mathrm{N}_{2} \mathrm{O}$ emissions from OWTS.

\section{Relationship between GHG flux and wastewater properties}

Understanding the relationships between effluent properties and GHG flux may be useful in controlling GHG emissions from advanced N-removal OWTS while also maintaining effective treatment. To this end, we performed regression analyses between wastewater properties and GHG flux using data across technologies, occupancy patterns, and sampling events, allowing us to examine the relationship between wastewater properties and flux at a broader scale. Because there were clear differences between zones in wastewater properties and GHG flux values, we performed separate analyses for L-OX and H-OX.

No relationships were found between any wastewater properties and GHG flux in H-OX, the oxic zone. $\mathrm{H}-\mathrm{OX}$ contains little organic matter and produced very low $\mathrm{CO}_{2}$ and $\mathrm{CH}_{4}$ fluxes in comparison with L-OX. In addition, we found no significant relationships between $\mathrm{N}_{2} \mathrm{O}$ flux 
and any wastewater property. $\mathrm{N}_{2} \mathrm{O}$ flux values were typically very low, which likely made it difficult to identify a relationship if one exists.

The flux of $\mathrm{CO}_{2}$ and $\mathrm{CH}_{4}$ in the anoxic/hypoxic zone was correlated with a number of wastewater properties (Fig. 4). There was a positive linear relationship between the $\mathrm{BOD}_{5}$ concentration and both $\mathrm{CO}_{2}$ and $\mathrm{CH}_{4}$ flux (Fig. 4), in line with the expectation that organic $\mathrm{C}$ in wastewater serves as substrate for heterotrophic microbial respiration. The relationship between flux of $\mathrm{CO}_{2}$ and $\mathrm{CH}_{4}$ and wastewater temperature was similar for both gases (Fig. 4). The flux increased with increasing temperature, peaking at $22-23^{\circ} \mathrm{C}$, and declining at higher temperatures, following a typical response of microbial activity to temperature (Apple et al., 2006).

There was an inverse relationship - best described by a negative power function between DO levels and the flux of $\mathrm{CH}_{4}$ and $\mathrm{CO}_{2}$ (Fig. 4). This indicates that, as expected, emissions of these two gases in the anoxic/hypoxic zone result from anaerobic respiration processes, including methanogenesis. Acetoclastic methanogenesis contributes significantly to anaerobic respiration in anoxic wastewater treatment environments (Qiao et al., 2015). The process produces equimolar amounts of $\mathrm{CH}_{4}$ and $\mathrm{CO}_{2}$. Linear regression analysis comparing $\mathrm{CH}_{4}$ flux with $\mathrm{CO}_{2}$ flux in L-OX confirmed this $1: 1$ relationship $\left(\right.$ slope $=1.2$; intercept $=3.5 ; R^{2}$ $=0.32$ ), suggesting that acetoclastic methanogenesis is an important driver of $\mathrm{CH}_{4}$ and $\mathrm{CO}_{2}$ emissions. Anaerobic respiration processes are sensitive to the introduction of $\mathrm{O}_{2}$, resulting in inhibition at DO levels greater than 2 mg/L (John, 1977; Hernandez \& Rowe, 1988; VaquerSunyer \& Duarte, 2008). The presence of $\mathrm{O}_{2}$ interferes with methanogenesis through at least two mechanisms: (i) by favoring aerobic metabolic processes, which have a more favorable energy yield than $\mathrm{CO}_{2}$, and (ii) through toxic effects on methanogenic Archaea, which are obligate anaerobes (Mer et al., 2001). 
We also observed an inverse relationship between $\mathrm{CO}_{2}$ and $\mathrm{CH}_{4}$ flux and nitrate concentration (Fig. 4). Others have reported negative effects of $\mathrm{N}_{\text {on }} \mathrm{CO}_{2}$ and $\mathrm{CH}_{4}$ flux. For example, the flux of $\mathrm{CO}_{2}$ from agricultural soil decreases in response to amendments with inorganic N (Ramirez et al., 2010), and Anderson et al. (2019) found that nitrate addition to soil amended with anoxic septic tank effluent lowered the flux of both $\mathrm{CO}_{2}$ and $\mathrm{CH}_{4}$. Nitrate is potentially toxic to some methanogens (Bollag \& Czlonkowski, 1973; Klüber \& Conrad, 1998), and its favorable energy yield as a terminal electron acceptor relative to $\mathrm{CO}_{2}$ can suppress methanogenesis. The inverse relationship between nitrate concentration and the flux of $\mathrm{CO}_{2}$ and $\mathrm{CH}_{4}$ in the anoxic/hypoxic zone may also reflect the intermittent introduction of aerated wastewater with a high concentration of DO from the oxic zone via recirculation.

Methane flux increased linearly with ammonium concentration, but there was no clear relationship between ammonium level and $\mathrm{CO}_{2}$ flux (Fig. 4). The flux of $\mathrm{CH}_{4}$ is the net result of gross methane production by methanogenic Archaea and gross consumption by methanotrophic bacteria. Ammonium is a competitive inhibitor of methane monooxygenase, the enzyme used by methanotrophs to oxidize $\mathrm{CH}_{4}$ (Norton et al., 2008; O’Neill \& Wilktnson, 1977; Schnell \& King, 1994). Thus, as the concentration of $\mathrm{NH}_{4}{ }^{+}$in wastewater increases, we would expect greater inhibition of $\mathrm{CH}_{4}$ oxidation and an increase in $\mathrm{CH}_{4}$ flux, assuming gross rates of methanogenesis remain constant.

The apparent response of $\mathrm{CH}_{4}$ and $\mathrm{CO}_{2}$ emissions to wastewater properties suggests that changes in some of these properties may be used to control the flux of these gases. For example, maintaining system temperature below $22-23^{\circ} \mathrm{C}$ - through the use of insulation around and over treatment compartments - may help limit $\mathrm{CH}_{4}$ and $\mathrm{CO}_{2}$ flux, provided the temperature is not so low that it interferes with performance. Increasing DO levels in wastewater - by changing 
recirculation ratios and/or mechanical aeration - could help also help mitigate $\mathrm{CO}_{2}$ and $\mathrm{CH}_{4}$ emissions from these systems. This would also increase nitrate levels, which may also curb emissions of these gases. However, the effluent would have to maintain oxygen levels low enough to allow for denitrification to take place to maintain effective $\mathrm{N}$ removal. Limited introduction of oxygen into the anoxic/hypoxic zone may also promote ammonia oxidation, reducing its inhibitory effect on methane oxidation. In contrast, although emissions increase with increasing concentration of $\mathrm{BOD}_{5}$, the latter is a function of homeowner lifestyle and cannot be controlled by changes in system operation. Manipulation of $\mathrm{BOD}_{5}$ levels is thus not a practical management strategy for limiting $\mathrm{CH}_{4}$ or $\mathrm{CO}_{2}$ emissions.

\section{$\mathrm{CO}_{2}$ Equivalents and Comparisons to Other Systems}

Greenhouse gases differ in global warming potential (GWP) due to differences in their residence time and reactivity in the atmosphere. According to the Intergovernmental Panel on Climate Change's Fifth Assessment (2014), $\mathrm{CH}_{4}$ and $\mathrm{N}_{2} \mathrm{O}$ have 28 and 265 times the GWP of $\mathrm{CO}_{2}$, respectively. Converting GHG flux values into $\mathrm{CO}_{2}$ equivalents $\left(\mathrm{CO}_{2} \mathrm{e}\right)$ accounts for these differences in GWP and allows us to assess the relative impact of individual gas fluxes on the atmosphere, and to compare emissions from advanced N-removal OWTS those from other wastewater treatment technologies. We calculated per capita emissions $\left(\mathrm{CO}_{2} \mathrm{e}\right.$; Brannon et al., 2017)f or each gas and for the sum of the three gases based on: (i) the average flux from L-OX and $\mathrm{H}-\mathrm{OX}$ at each system across all sampling events, (ii) the cross-sectional area of the tank, and (iii) the assumption that each system serves a household of 3 people (Amador et al., 2018). Advanced N-removal OWTS contributed a median of 40, 176, and $9 \mathrm{~g} \mathrm{CO}_{2} \mathrm{e} \mathrm{capita}^{-1}$ day $^{-1}$ for $\mathrm{CO}_{2}, \mathrm{CH}_{4}$, and $\mathrm{N}_{2} \mathrm{O}$, respectively (Fig. 5), with methane emissions accounting for a the bulk of 
the impact of these systems on the atmosphere. The median sum of emissions from advanced N-

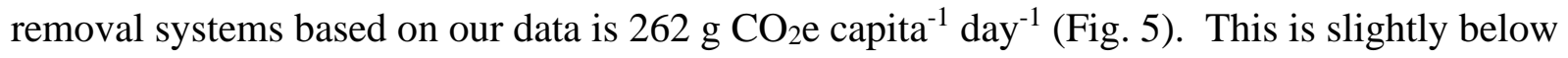
the range of values reported by Diaz-Valbuena et al. (2011) of $277 \mathrm{~g} \mathrm{CO}_{2} \mathrm{e}$ capita $^{-1} \mathrm{day}^{-1}$ for a conventional OWTS, and by Truhlar et al. (2016), who found that the roof vent of a conventional OWTS, which releases gases produced in the septic tank, produced an average of $469 \mathrm{~g} \mathrm{CO}_{2} \mathrm{e}$ capita $^{-1}$ day $^{-1}$. Our systems produced more $\mathrm{CH}_{4}\left(176 \mathrm{CO}_{2}\right.$ e capita ${ }^{-1}$ day $\left.^{-1}\right)$ and less $\mathrm{N}_{2} \mathrm{O}\left(9 \mathrm{CO}_{2} \mathrm{e}\right.$ capita $^{-1}$ day $^{-1}$ ) when compared with values for centralized WTPs in the U.S of 99 and $52 \mathrm{CO}_{2} \mathrm{e}$ capita $^{-1}$ day $^{-1}$, for $\mathrm{CH}_{4}$ and $\mathrm{N}_{2} \mathrm{O}$, respectively (USEPA, 2015). Higher emissions of $\mathrm{CH}_{4}$ from OWTS are not surprising, since organic $\mathrm{C}$, which is a major driver behind $\mathrm{CH}_{4}$ emissions, is present in higher concentrations in OWTS than in centralized WTPs, where organic C inputs are diluted by large volumes of water with low organic C content (Amador \& Loomis, 2018).

Our results indicate that, despite the enhanced microbial activity facilitated by increased aeration and system design, advanced N-removal OWTS do not have higher total GHG emissions than conventional OWTS. Advanced N-removal OWTS may have an even lower impact than conventional systems on the atmosphere if we consider emissions from the soil treatment area (STA). Final effluent from advanced OWTS has a much lower organic C concentration than septic tank effluent from a conventional system (Amador and Loomis, 2018). This translates into lower amounts of substrate and lower $\mathrm{CO}_{2}$ emissions from heterotrophic microbial processes when effluent is dispersed to the STA. A lower concentration of organic compounds such as acetate - the substrate for acetoclastic methanogenesis - in effluent from advanced N-removal OWTS may also result in lower $\mathrm{CH}_{4}$ emissions from the STA. 


\section{Conclusions}

Advanced N-removal OWTS rely on microbial processes for wastewater treatment, and thus inevitably emit GHGs. Our study provides the first comprehensive assessment of GHG emissions from advanced N-removal OWTS. We observed differences in $\mathrm{CO}_{2}$ and $\mathrm{N}_{2} \mathrm{O}$, but not $\mathrm{CH}_{4}$, flux based on technology, suggesting that system design and/or dosing mechanism may influence emissions of these gases. Home occupancy did not significantly impact the flux of any of the three gases measured, suggesting that daily GHG emissions are not affected by seasonal and year-round usage patterns and associated differences in the volume of wastewater inputs. The flux of $\mathrm{CO}_{2}$ and $\mathrm{CH}_{4}$ - but not $\mathrm{N}_{2} \mathrm{O}$ - was significantly higher in the anoxic/hypoxic zone than in the oxic zone. The flux of both gases - but not $\mathrm{N}_{2} \mathrm{O}$ - in the anoxic/hypoxic zone was related to wastewater properties, including $\mathrm{BOD}_{5}$ concentration, temperature, $\mathrm{DO}$ and inorganic $\mathrm{N}$ levels, providing an opportunity to mitigate GHG emissions through manipulation of some of these properties. $\mathrm{N}_{2} \mathrm{O}$ fluxes from advanced $\mathrm{N}$-removal OWTS appear to be minimal, accounting for a small fraction of total $\mathrm{CO}_{2} \mathrm{e}$ from these systems.

Daily per capita $\mathrm{CO}_{2} \mathrm{e}$ for advanced N-removal OWTS were slightly lower than those for conventional OWTS. It appears that, despite the enhanced biological $\mathrm{N}$ removal that takes place in advanced OWTS, their contribution to atmospheric pollution is not different from that for systems that remove considerably less $\mathrm{N}$ from wastewater.

\section{Acknowledgements}

This work was funded by the USDA National Institute of Food and Agriculture, Hatch Multi-State NE 1545 Project [accession number 1007770], the Rhode Island Science and Technology Advisory Council $(05098,2016)$, and by a grant $(00 \mathrm{~A} 000128-0)$ awarded by the U. 
S. Environmental Protection Agency to Jose Amador and George Loomis at the University of Rhode Island.

We thank our regulatory partners at the Rhode Island Department of Environmental Management and the town of Charlestown, Rhode Island for assisting with technical aspects of the project and procuring study sites. We also thank the Charlestown homeowners who allowed us to study their advanced N-removal OWTS. Special thanks go to Matt Dowling, Kevin Hoyt, Connor Silverman, and Fidaa Janoudi for their technical and field support, and to Caleb Martin and Rose Martin for providing the R script used to analyze GHG fluxes.

Although the information in this paper has been funded wholly or in part by the U.S. Environmental Protection Agency, it has not undergone the Agency's publications review process and therefore may not necessarily reflect the views of the Agency; no official endorsement should be inferred. The viewpoints expressed here do not necessarily represent those of the town of Charlestown, the Rhode Island Department of Environmental Management, or the U. S. Environmental Protection Agency, nor does mention of trade names, commercial products, or causes constitute endorsement or recommendation for use. 


\section{Figures}

$1 \mathrm{~A}$
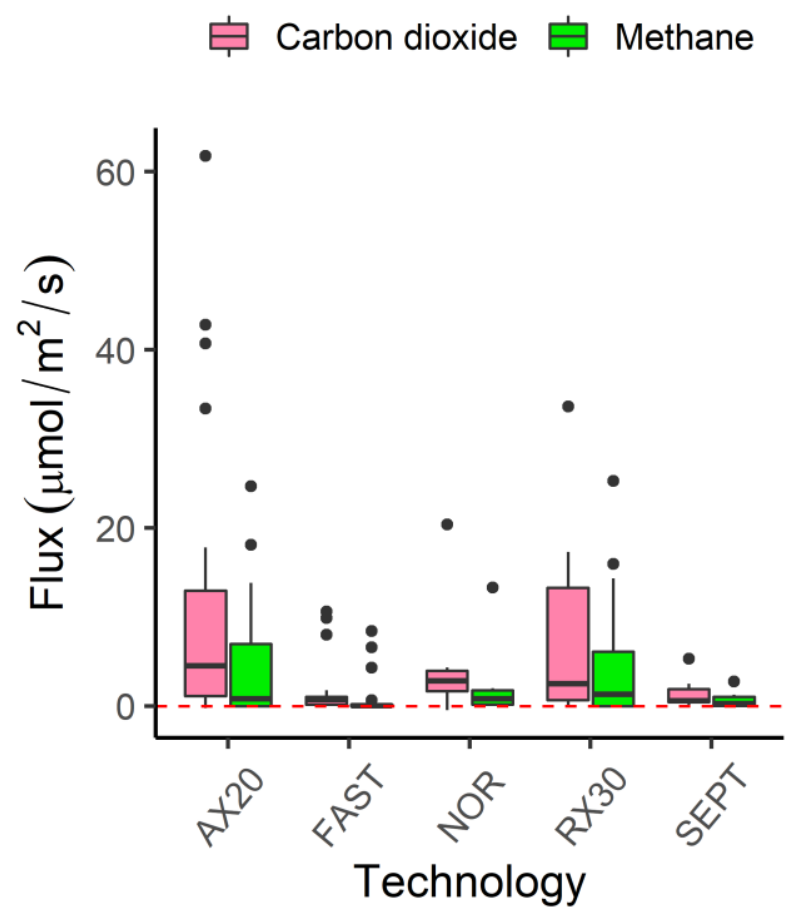

1B

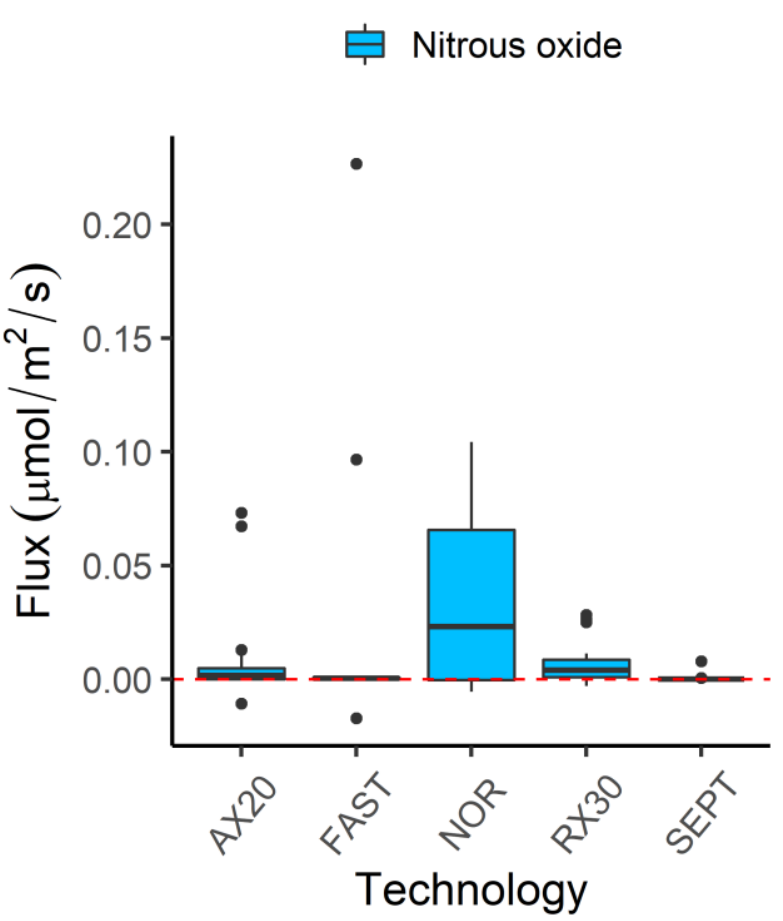

Figure 1. Carbon dioxide, methane, and nitrous oxide fluxes from different advanced N-removal OWTS technologies across all home occupancy patterns, sampling dates, and system zones (LOX and H-OX). AX20 = Orenco Advantex ${ }^{\circledR}$ AX20 (9 systems, $\left.n=30\right)$; FAST = BioMicrobics MicroFAST® (6 systems, $n=19)$; NOR = Norweco Singulair ${ }^{\circledR}(3$ systems, $n=6) ; \mathrm{RX} 30=$ Orenco Advantex ${ }^{\circledR}$ RX30 (6 systems, $\left.n=20\right)$; SEPT $=$ SeptiTech ${ }^{\circledR}$ Series D (3 systems, $n=12$ ). 
$2 A$

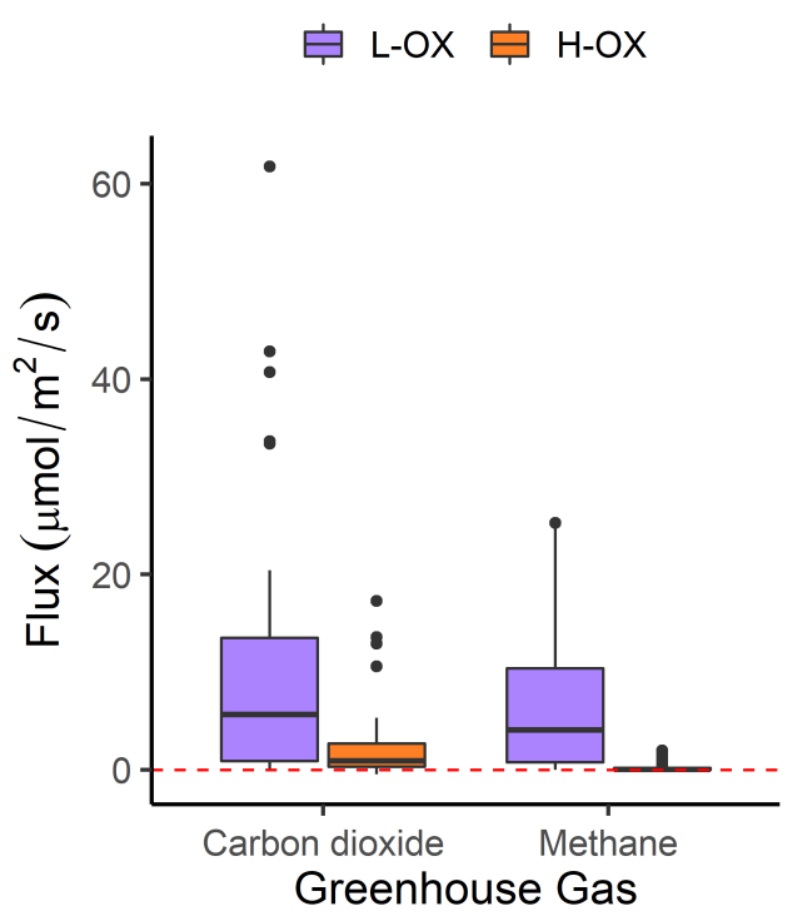

$2 \mathrm{~B}$
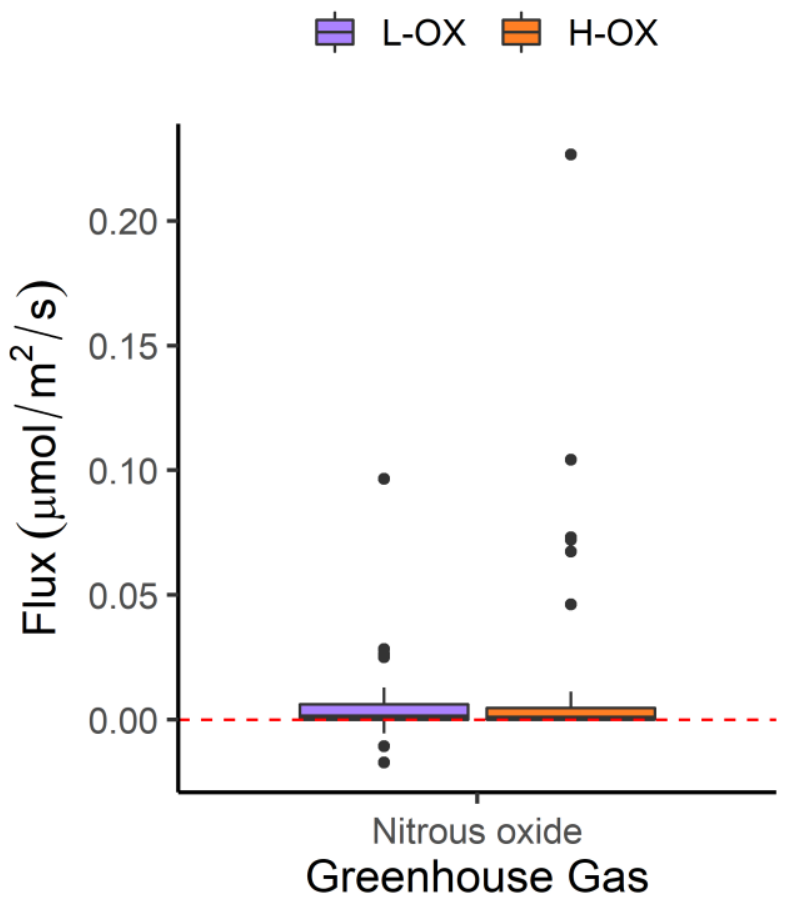

Figure 2. Carbon dioxide, methane, and nitrous oxide fluxes from the anoxic/hypoxic zone (L$\mathrm{OX}, n=25-36)$ and the oxic zone (H-OX, $n=42-43)$ across technologies, home occupancy patterns, and sampling dates. 
$3 \mathrm{~A}$

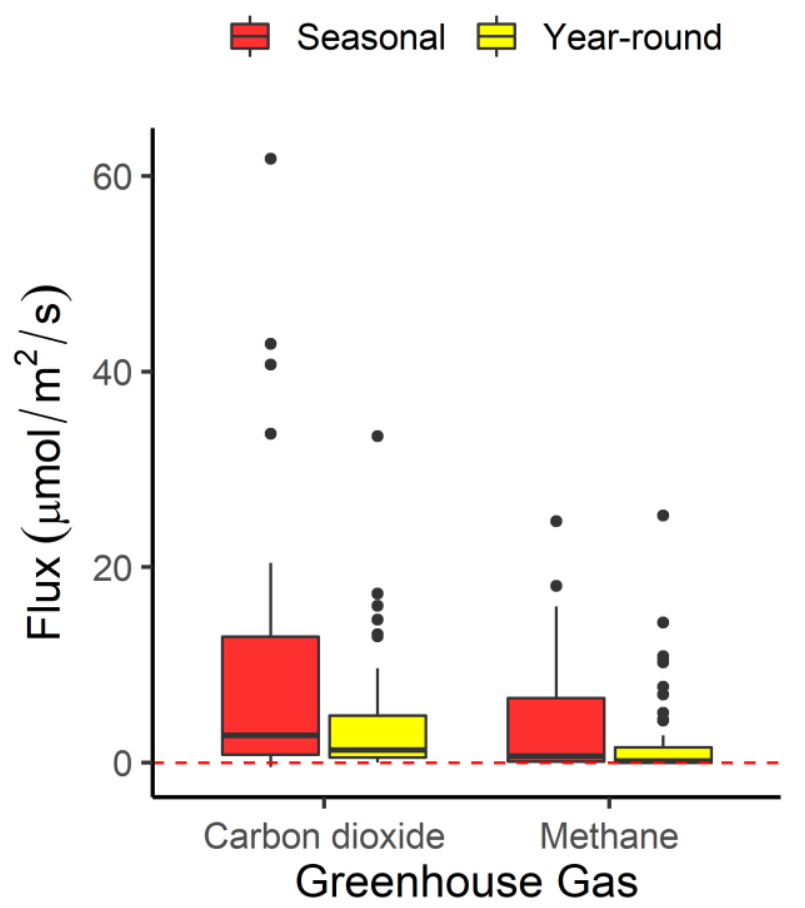

3B

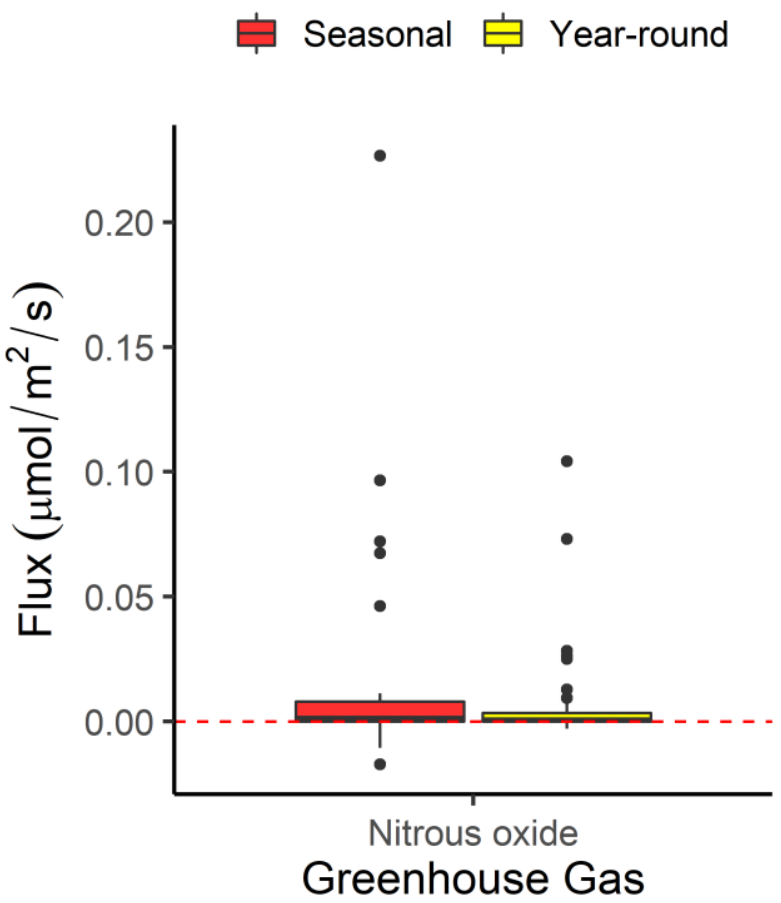

Figure 3. Carbon dioxide, methane, and nitrous oxide fluxes from systems used seasonally ( $n=$ 28-29) and year-round ( $n=49-50)$ across all technologies, system zones, and sampling dates. 

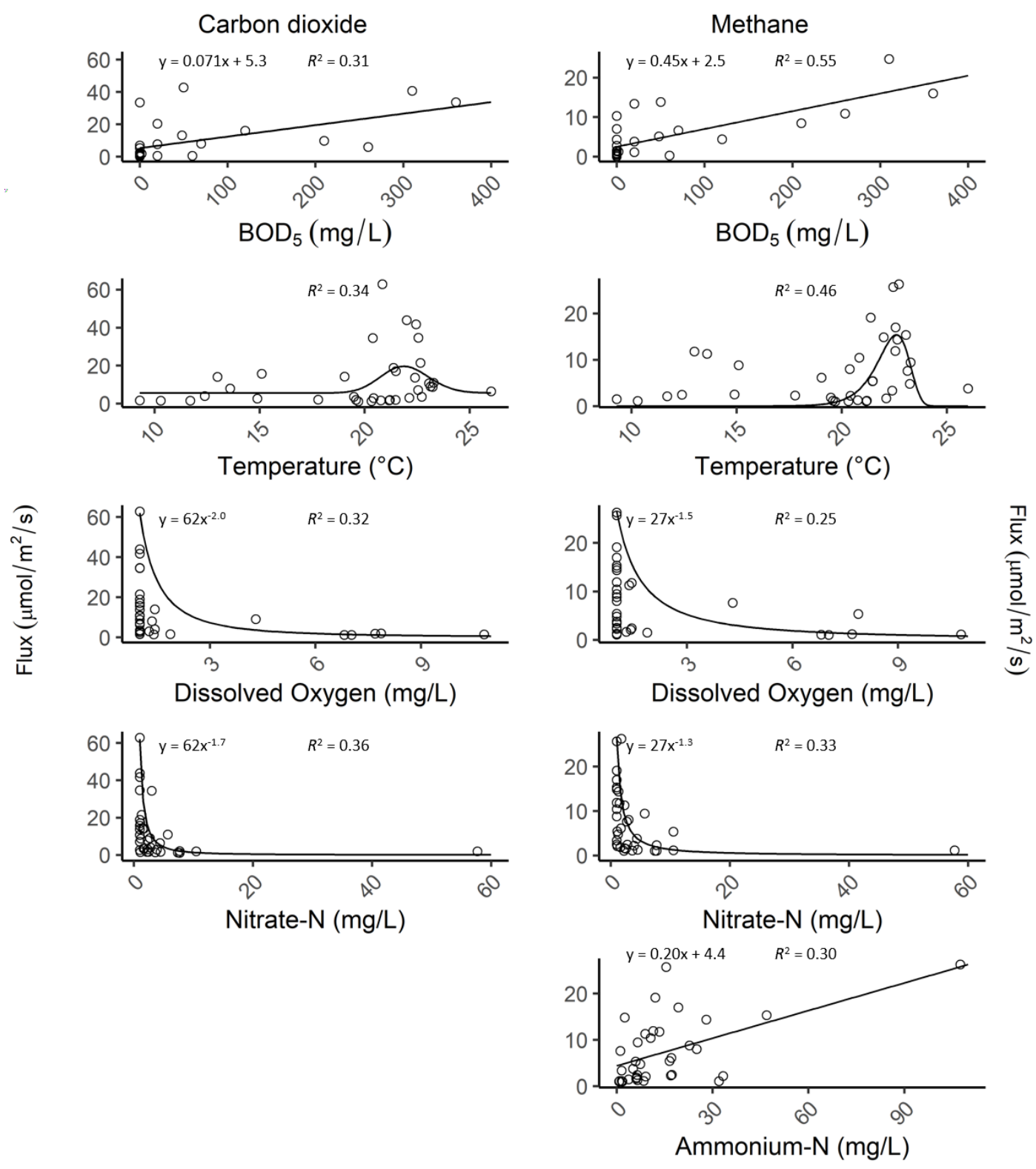

Figure 4. Relationship between wastewater properties and $\mathrm{CH}_{4}$ and $\mathrm{CO}_{2}$ fluxes in the anoxic/hypoxic zone (L-OX) of advanced N-removal OWTS. Best-fit line is shown in black. The regression parameters and equations for the temperature regressions can be found in the Supplemental Materials. 


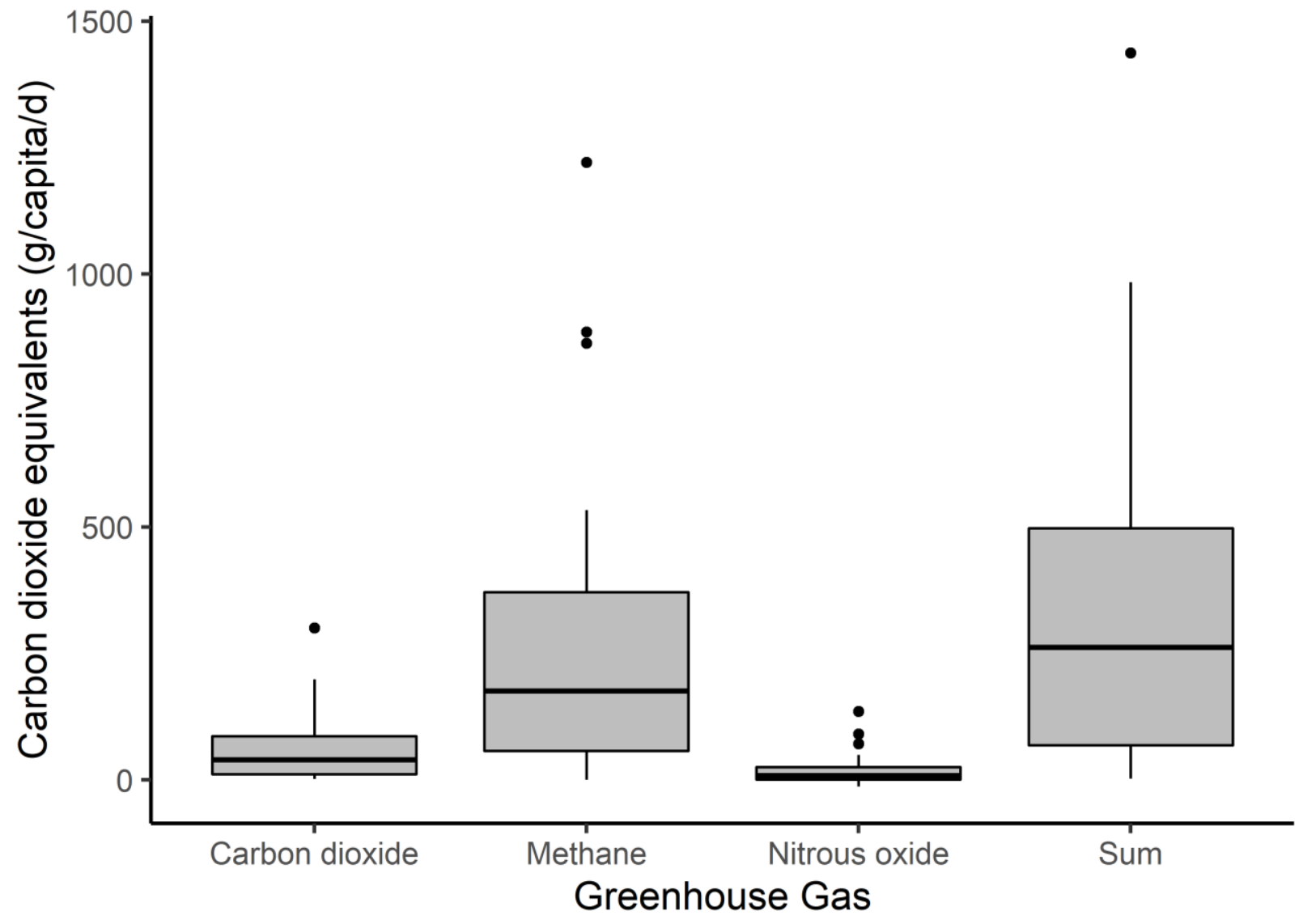

Figure 5. Carbon dioxide equivalent emissions $(n=85)$ of carbon dioxide, methane, and nitrous oxide, and sum of all GHGs across all technologies, home occupancy patterns, sampling dates, and system zones. 


\section{References}

Amador, J. A., Görres, J. H., Loomis, G. W., \& Lancellotti, B. V. (2018). Nitrogen Loading from Onsite Wastewater Treatment Systems in the Greater Narragansett Bay (Rhode Island, USA) Watershed: Magnitude and Reduction Strategies. Water, Air, and Soil Pollution, 229(3). https://doi.org/10.1007/s11270-018-3714-4

Amador, J., \& Loomis, G. (2018). Soil-based Wastewater Treatment. Madison, WI: American Society of Agronomy, Inc., Soil Science Society of America, Inc., Crop Science Society of America, Inc.

Anderson, F. L., Cooper, J. A., \& Amador, J. A. (2019). Laboratory-Scale Evaluation of the Effects of Water-Filled Pore Space on Emissions of CO 2, CH 4, N 2 O, and N 2 from SoilBased Wastewater Treatment. Water, Air, \& Soil Pollution, 230(10), 245. https://doi.org/10.1007/s11270-019-4294-7

Apple, J. K., Del Giorgio, P. A., \& Kemp, W. M. (2006). Temperature regulation of bacterial production, respiration, and growth efficiency in a temperate salt-marsh estuary. Aquatic Microbial Ecology, 43(3), 243-254. https://doi.org/10.3354/ame043243

Beaulieu, J. J., Nietch, C. T., \& Young, J. L. (2015). Controls on nitrous oxide production and consumption in reservoirs of the Ohio River Basin. Journal of Geophysical Research: Biogeosciences, 120(10), 1995-2010. https://doi.org/10.1002/2015JG002941

Bollag, J. M., \& Czlonkowski, S. T. (1973). Inhibition of methane formation in soil by various nitrogen-containing compounds. Soil Biology and Biochemistry, 5(5), 673-678. https://doi.org/10.1016/0038-0717(73)90057-6

Brannon, E. Q., Moseman-Valtierra, S. M., Lancellotti, B. V., Wigginton, S. K., Amador, J. A., McCaughey, J. C., \& Loomis, G. W. (2017). Comparison of N O Emissions and Gene Abundances between Wastewater Nitrogen Removal Systems. Journal of Environment Quality, 46(5), 931. https://doi.org/10.2134/jeq2017.03.0092

Cakir, F. Y., \& Stenstrom, M. K. (2005). Greenhouse gas production: A comparison between aerobic and anaerobic wastewater treatment technology. Water Research, 39(17), 41974203. https://doi.org/10.1016/j.watres.2005.07.042

Carpenter, S. R., Caraco, N. F., Correll, D. L., Howarth, R. W., Sharpley, A. N., \& Smith, V. H. (1998). NONPOINT POLLUTION OF SURFACE WATERS WITH PHOSPHORUS AND NITROGEN S. (Vol. 8). https://doi.org/10.1890/10510761(1998)008[0559:NPOSWW]2.0.CO;2

Chapuis-lardy, L., Wrage, N., Metay, A., Chotte, J. L., \& Bernoux, M. (2007). Soils, a sink for N 2 O? A review. Global Change Biology, 13(1), 1-17. https://doi.org/10.1111/j.13652486.2006.01280.x 
Crosson, E. R. (2008). A cavity ring-down analyzer for measuring atmospheric levels of methane, carbon dioxide, and water vapor. Applied Physics B: Lasers and Optics, 92(3 SPECIAL ISSUE), 403-408. https://doi.org/10.1007/s00340-008-3135-y

Diaz-Valbuena, L.R., H.L. Leverenz, C.D. Cappa, G. Tchobanoglous, W.R. Hor- wath, \& J.L. Darby. 2011. Methane, carbon dioxide, and nitrous oxide emissions from septic tank systems. Environ. Sci. Technol. 45:2741-2747. doi:10.1021/es1036095

Doorn, M. R. J., Towprayoon, S., Manso Vieira, S. M., Irving, W., Palmer, C., Pipatti, R., \& Wang, C. (2006). 2006 IPCC Guidelines for National Greenhouse Gas Inventories: Chapter 6 Wastewater Treatment and Discharge. 2006 IPCC Guidelines for National Greenhouse Gas Inventories, 1-28. https://doi.org/WAS-01

Foley, J., de Haas, D., Yuan, Z., \& Lant, P. (2010). Nitrous oxide generation in full-scale biological nutrient removal wastewater treatment plants. Water Research, 44(3), 831-844. https://doi.org/10.1016/j.watres.2009.10.033

Griffith, D. R., Barnes, R. T., \& Raymond, P. A. (2009). Inputs of fossil carbon from wastewater treatment plants to U.S. Rivers and oceans. Environmental Science and Technology, 43(15), 5647-5651. https://doi.org/10.1021/es9004043

Hernandez, D., \& Rowe, J. J. (1988). Oxygen inhibition of nitrate uptake is a general regulatory mechanism in nitrate respiration. Journal of Biological Chemistry, 263(17), 7937-7939.

IPCC, 2014: Climate Change 2014: Mitigation of Climate Change. Contribution of Working Group III to the Fifth Assessment Report of the Intergovernmental Panel on Climate Change [Edenhofer, O., R. Pichs-Madruga, Y. Sokona, E. Farahani, S. Kadner, K. Seyboth, A. Adler, I. Baum, S. Brunner, P. Eickemeier, B. Kriemann, J. Savolainen, S. Schlömer, C. von Stechow, T. Zwickel and J.C. Minx (eds.)]. Cambridge University Press, Cambridge, United Kingdom and New York, NY, USA

John, P. (1977). Aerobic and anaerobic bacterial respiration monitored by electrodes. Journal of General Microbiology, 98(1), 231-238. https://doi.org/10.1099/00221287-98-1-231

Jones, C. M., Graf, D. R. H., Bru, D., Philippot, L., \& Hallin, S. (2013). The unaccounted yet abundant nitrous oxide-reducing microbial community: A potential nitrous oxide sink. ISME Journal, 7(2), 417-426. https://doi.org/10.1038/ismej.2012.125

Klüber, H. D., \& Conrad, R. (1998). Inhibitory effects of nitrate, nitrite, NO and N2O on methanogenesis by Methanosarcina barkeri and Methanobacterium bryantii. FEMS Microbiology Ecology, 25(4), 331-339. https://doi.org/10.1016/S0168-6496(97)00102-5

Kong, Q., Wang, Z. bin, Niu, P. fei, \& Miao, M. sheng. (2016). Greenhouse gas emission and microbial community dynamics during simultaneous nitrification and denitrification process. Bioresource Technology, 210, 94-100. https://doi.org/10.1016/j.biortech.2016.02.051 
Lancellotti, B. V., Loomis, G. W., Hoyt, K. P., Avizinis, E., \& Amador, J. A. (2017). Evaluation of Nitrogen Concentration in Final Effluent of Advanced Nitrogen-Removal Onsite Wastewater Treatment Systems (OWTS). Water, Air, and Soil Pollution, 228(10). https://doi.org/10.1007/s11270-017-3558-3

Law, Y., Jacobsen, G. E., Smith, A. M., Yuan, Z., \& Lant, P. (2013). Fossil organic carbon in wastewater and its fate in treatment plants. Water Research, 47(14), 5270-5281. https://doi.org/10.1016/j.watres.2013.06.002

Law, Y., Ye, L., Pan, Y., \& Yuan, Z. (2012). Nitrous oxide emissions from wastewater treatment processes. Philosophical Transactions of the Royal Society B: Biological Sciences, 367(1593), 1265-1277. https://doi.org/10.1098/rstb.2011.0317

Mer, J. Le, Roger, P., Provence, D., \& Luminy, D. (2001). Production, oxidation, emission, and consumption of methan by soils: A review. Archaea, 37, 25-50.

Norton, J. M., Schepers, J. S., \& Raun, W. R. (2008). Nitrification in Agricultural Soils. https://doi.org/10.2134/agronmonogr49.c6

O’Neill, J. G., \& Wilktnson, J. F. (1977). Oxidation of Ammonia by Methane-oxidizing Bacteria and. Journal of General Microbiology, 100, 407-412. Retrieved from https://www.microbiologyresearch.org/docserver/fulltext/micro/100/2/mic-100-2407.pdf?expires $=1549569237 \& \mathrm{id}=\mathrm{id} \&$ accname $=$ guest $\&$ checksum=D1E93EE44F91FD2F8 1AA52B053E948CE

Parravicini, V., Svardal, K., \& Krampe, J. (2016). Greenhouse Gas Emissions from Wastewater Treatment Plants. Energy Procedia, 97, 246-253. https://doi.org/10.1016/j.egypro.2016.10.067

Qiao, S., Tian, T., Qi, B., \& Zhou, J. (2015). Methanogenesis from wastewater stimulated by addition of elemental manganese. Scientific reports, 5, 12732.

R Core Team (2017). R: A language and environment for statistical computing. R Foundation for Statistical Computing, Vienna, Austria. URL https:/www.R-project.org/

Ramirez, K. S., Craine, J. M., \& Fierer, N. (2010). Nitrogen fertilization inhibits soil microbial respiration regardless of the form of nitrogen applied. Soil Biology and Biochemistry, 42(12), 2336-2338. https://doi.org/10.1016/j.soilbio.2010.08.032

Renforth, P. (2019). The negative emission potential of alkaline materials. Nature Communications, 10(1). https://doi.org/10.1038/s41467-019-09475-5

Ross, B. N., Hoyt, K. P., Loomis, G. W., \& Amador, J. A. (A) (2020). Assessing drivers of nitrogen removal in advanced onsite wastewater treatment systems in a Rhode Island coastal community. Manuscript in preparation for Water, Air, \& Soil Pollution 
Ross, B. N., Wigginton, S. K., Cox, A. H., Loomis, G. W., \& Amador, J. A. (B) (2020). Influence of season, occupancy pattern, and technology on structure and composition of nitrifying and denitrifying bacterial communities in advanced nitrogen-removal onsite wastewater treatment systems. Manuscript in preparation for Water

Schnell, S., \& King, G. M. (1994). Mechanistic analysis of ammonium inhibition of atmospheric methane consumption in forest soils. Applied and Environmental Microbiology, 60(10), $3514-3521$.

Sohail, M., \& Adeloju, S. B. (2016). Nitrate biosensors and biological methods for nitrate determination. Talanta, 153, 83-98. https://doi.org/10.1016/j.talanta.2016.03.002

Somlai-Haase, C., Knappe, J., \& Gill, L. (2017). Carbon dioxide emissions from a septic tank soakaway in a northern maritime climate. Science of the Total Environment, 586, 485-491. https://doi.org/10.1016/j.scitotenv.2017.01.206

Soued, C., Del Giorgio, P. A., \& Maranger, R. (2016). Nitrous oxide sinks and emissions in boreal aquatic networks in Quebec. Nature Geoscience, 9(2), 116-120. https://doi.org/10.1038/ngeo2611

Truhlar, A. M., Rahm, B. G., Brooks, R. A., Nadeau, S. A., Makarsky, E. T., \& Walter, M. T. (2016). Greenhouse Gas Emissions from Septic Systems in New York State. Journal of Environment Quality, 45(4), 1153. https://doi.org/10.2134/jeq2015.09.0478

Tseng, L. Y., Robinson, A. K., Zhang, X., Xu, X., Southon, J., Hamilton, A. J., ... Rosso, D. (2016). Identification of Preferential Paths of Fossil Carbon within Water Resource Recovery Facilities via Radiocarbon Analysis. Environmental Science and Technology, 50(22), 12166-12178. https://doi.org/10.1021/acs.est.6b02731

U.S. Census Bureau. (2017). Quick facts: Rhode Island. Available at: https://www.census.gov/quickfacts/table/PST045216/44

U.S. Census Bureau. (2018). QuickFacts Charlestown town, Washington County, Rhode Island. Retrieved from https://www.census.gov/quickfacts/charlestowntownwashingtoncountyrhodeisland

U.S. Environmental Protection Agency. (2015). Inventory of U.S. Greenhouse Gas Emissions and Sinks: 1990 - 2013 (Report 430-R-15-004). Washington, DC.

Vaquer-Sunyer, R., \& Duarte, C. M. (2008). Thresholds of hypoxia for marine biodiversity. Proceedings of the National Academy of Sciences of the United States of America, 105(40), 15452-15457. https://doi.org/10.1073/pnas.0803833105

Ward, M. H., deKok, T. M., Levallois, P., Brender, J., Gulis, G., Nolan, B. T., \& VanDerslice, J. (2005). Workgroup report: Drinking-water nitrate and health - Recent findings and research 
needs. Environmental Health Perspectives, 113(11), 1607-1614.

https://doi.org/10.1289/ehp.8043

Wigginton, S. K., E. Q. Brannon, P. J. Kearns, B. V. Lancellotti, Alissa Cox, S. MosemanValtierra, G. W. Loomis, and J. A. Amador. 2020. Microbial communities in centralized and decentralized biological nitrogen removing wastewater treatment systems. In preparation for submission to Water.

Yan, X., Li, L., \& Liu, J. (2014). Characteristics of greenhouse gas emission in three full-scale wastewater treatment processes. Journal of Environmental Sciences, 26(2), 256-263. https://doi.org/10.1016/S1001-0742(13)60429-5 